\title{
Pemanfaatan Kvisoft Flipbook Maker dalam Rangka Peningkatan Hasil Belajar Peserta Didik
}

\author{
Zulhelmi $^{1^{*} \text { (iD }}$ \\ ${ }^{I}$ Program Studi Pendidikan Teknologi dan Kejuruan, Fakultas Teknik, Universitas Negeri Padang, Indonesia \\ *Corresponding author: eelaqilah@gmail.com
}

\begin{abstract}
Abstrak
Hasil belajar siswa dalam mengikuti pembelajaran daring menurun, hal ini disebabkan karena siswa mengalami berbagai kesulitan dalam memahami materi. Tujuan penelitian menerapkan e-modul aplikasi Kvisoft Flipbook maker dalam rangka meningkatkan hasil belajar. Jenis penelitian yang digunakan semi eksperimental plan kuantitatif. Populasi penelitian adalah peserta didik semester 3 dan 5 dengan jumlah 40 orang, untuk Program Keahlian Teknik Elektronika dengan Kompetensi Keahlian Teknik Audio Video di SMK. Teknik pengambilan sampel (sampling) yang digunakan yaitu purposive sampling (purposive testing). Jumlah sample tersebut digunakanlah perbandingan antara jumlah tiap kelas dibagi dengan jumlah total dari kedua kelas (jumlah populasi) dan dikalikan dengan jumlah sample yang telah ditetapkan sebelumnya. Kelas kontrol berjumlah 8 siswa dan kelas eksperimen berjumlah 12 siswa. Teknik pengumpulan data penelitian menggunakan teknik kuesioner dan tes hasil belajar. Teknik analisis menggunakan measurement (statistic) deskriptif, persentase, dan uji T. Hasil penelitian rata-rata sebelum untuk kelas eksperimen sebesar 55,00 dan sesudahnya sebesar 65. Dari hasil perhitungan ini dapat sama-sama terdapatnya perbedaan nilai peserta didik sebelum dan sesudah menggunakan Kvisoft flipbook maker untuk materi teknik pembuatan PCB secara manual. Tabel 6 merupakan hasil uji hipotesis Paired T-Test untuk kelas eksperimen dengan kepercayaan 95\%, dimana diperoleh nilai signifikasi $0,000<0,05$, maka hipotesis diterima. Maka pemanfaatan kvisoft flipbook maker dapat meningkatkan hasil belajar peserta didik.
\end{abstract}

Kata kunci: Kvisoft Flipbook maker, Hasil Belajar

\section{Abstract}

Student learning outcomes in participating in online learning decreased, this was because students experienced various difficulties in understanding the material. The research objective is to implement the Kvisoft Flipbook maker e-module application in order to improve learning outcomes. This type of research used a quantitative semi-experimental plan. The research population is students in semester 3 and 5 with a total of 40 people, for the Electronic Engineering Expertise Program with Audio Video Engineering Skills Competence in Vocational Schools. The sampling technique used is purposive sampling (purposive testing). The number of samples used is the comparison between the number of each class divided by the total number of the two classes (the number of population) and multiplied by the number of samples that have been previously determined. The control class consisted of 8 students and the experimental class consisted of 12 students. Research data collection techniques using questionnaires and learning outcomes tests. The analysis technique uses descriptive measurement (statistics), percentages, and T-test. The average research results before for the experimental class is 55.00 and after that is 65. From the results of this calculation, it can be seen that there are both differences in student scores before and after using Kvisoft flipbook maker for manual PCB manufacturing techniques. Table 6 is the result of the Paired T-Test hypothesis test for the experimental class with 95\% confidence, where a significance value of $0.000<0.05$ is obtained, then the hypothesis is accepted. So the use of kvisoft flipbook maker can improve student learning outcomes.

Keywords: Kvisoft Flipbook Maker, Learning outcomes

\begin{tabular}{lll}
\hline History: & Publisher: Undiksha Press \\
Received & $:$ 17 Januari 2021 & Licensed: This work is licensed under \\
Revised & $:$ 30 Januari 2021 & a Creative Commons Attribution 4.0 License \\
Accepted & $:$ 25 Mei 2021 & cC) (P) \\
Published & $:$ 25 Juli 2021 &
\end{tabular}

\section{Pendahuluan}

Perkembangan ilmu dan teknologi yang begitu pesat, sehingga membuat dunia pendidikan saat ini memasuki yang namanya masa-masa dunia teknologi (Dewi et al., 2019; Rahmadi et al., 2018). Proses pembelajaran menuntut untuk lebih mengarah pada penggunaan media dalam pembelajaran (Aka, 2017; Widiyono, 2020). Teknologi yang 
digunakan secara tepat untuk pendidikan dapat meningkatkan kualitas belajar peserta didik. Kegiatan pembelajaran tidak terlepas dari tenaga pendidik dan bahan ajarnya (Hudayati et al., 2021; Prasojo et al., 2019). Penggunaan media elektronik sangat berdampak positif dalam komposisi pembelajaran (Kristin, 2016; Puspitawangi, R.K., 2017). Oleh karena itu, tidak menutup kemungkinan bahwa tenaga pendidik dituntut untuk menguasai perkembangan ilmu dan teknologi yang ada serta menyediakan media pembelajaran yang membuat peserta didik menjadi lebih aktif. Bentuk dari fasilitas pembelajaran yang dapat memberikan pengaruh terhadap kualitas pemahaman dan keterampilan peserta didik adalah ketersediaan dan pemanfaatan media pembelajaran (Indahini et al., 2018; Novianto et al., 2018). Media belajar mandiri pada masa sekarang adalah memanfaatkan teknologi informasi dan komunikasi dalam pembelajaran dan kehidupan sehari-hari (Hudayati et al., 2021; Rivalina, 2014). Tenaga pendidik harus berupaya untuk menciptakan peserta didik yang berkualitas dan lebih aktif dalam pembelajaran.

Banyak permasalahan yang dihadapi oleh pendidik selama pembelajaran daring tersebut, salah satunya adalah siswa kurang interest dalam pembelajaran sehingga banyak peserta didik yang tidak mengikuti pembelajaran daring tersebut (Asmuni, 2020; Rigianti, 2020; Wijayanti \& Fauziah, 2020). Hasil belajar siswa dalam mengikuti pembelajaran daring menurun, hal ini disebabkan karena siswa mengalami berbagai kesulitan dalam memahami materi (Ota et al., 2021; Siahaan, 2020). Selain itu guru dalam mengajar hanya menggunakan sumber belajar berupa buku(Anugrahana, 2020; Pakpahan \& Fitriani, 2020). Suatu proses pembelajaran dikatakan baik apabila didukung oleh sumber belajar atau bahan ajar yang baik dan berkualitas (Kuncahyono, 2018; Sasmito \& Trimulyono, 2019). Untuk menghadapi situasi sedemikian rupa maka penulis merancang dan membuat sebuah perangkat pembelajaran. Salah satu perangkat pembelajaran yang dapat menunjang proses pembelajaran yaitu modul. Modul merupakan media atau sarana pembelajaran yang berisi materi, metode, batasan-batasan materi pembelajaran, petunjuk kegiatan pembelajaran, latihan dan cara mengevaluasi yang dirancang secara sistematis dan menarik untuk mencapai kompetensi yang diharapkan dan digunakan secara mandiri (Susilowati et al., 2018; Wibowo, 2018).

E-Modul pembelajaran untuk menarik dan mempermudah peserta didik dalam memahami sebuah materi (Nakayama, M \& Yamamoto., 2006; Suwasono, 2013). E-Modul yang menggunakan aplikasi Kvisoft flipbook maker dapat meningkatkan interaksi antara pendidik dan peserta didik dalam pembelajaran jarak jauh serta peserta didik lebih tertarik menggunakan E-Modul yang menggunakan aplikasi Kvisoft flipbook maker dalam pembelajaran (Szép, 2017; Wibowo \& Pratiwi, 2018). Selain itu adanya peningkatan keinginan peserta didik dalam mengikuti pembelajaran Kerja Bengkel dan Gambar Teknik dengan materi pembelajaran yaitu teknik pembuatan PCB secara manual. Perkembangan $E$ Modul sudah semakin berkembang salah satu bentuk E-Modul yang diharapkan dapat mempermudah pemahaman peserta didik dalam materi teknik pembuatan PCB secara manual.

Temuan penelitian sebelumnya menyatakan E-modul dapat membantu siswa dalam proses pembelajaran (Fonda \& Sumargiyani, 2018; Kuncahyono \& Aini, 2020; Winatha et al., 2018). E-Modul hanya dapat disajikan melalui beberapa aplikasi, seperti : 3D page flip profesional, Calibre, Sigil, Mobil pocket Creator, MS Word To EPUB Converter, ePUBee Maker, Kvisoft flipbook maker, flip book maker HTML, flipbook pdf dan lain-lain (Ferdianto \& Nurulfatwa, 2019; Kulagina et al., 2021; Sa'diyah, 2021). Penelitian sebelumnya menggunakan Kvisoft flip book maker namun apabila tidak memiliki aplikasi tersebut maka kita tidak bisa melihat isi dari E-Modul tersebut. E-Modul yang menggunakan aplikasi Kvisoft flipbook maker ini bisa dilihat dari HP, TAB, Laptop dan Komputer tanpa harus menggunakan aplikasinya. E-Modul ini hasil penyajiannya dalam bentuk elektronik didalamnya mampu menampilkan simulasi-simulasi yang interaktif dengan memadukan teks, 
gambar, sound, video, animasi, dan navigasi sehingga pembelajaran dapat berlangsung lebih menarik dan menyenangkan serta membuat peserta didik lebih tertarik dalam mengikuti pembelajaran dengan materi teknik pembuatan PCB secara manual. Tujuan dari penelitian ini adalah untuk menganalisis pemanfaatan kvisoft flipbook maker dalam rangka peningkatan hasil belajar peserta didik. Adanya penggunaan E-modul ini dapat meningkatkan hasil belajar peserta didik dan peserta didik semangat dan termotivasi dalam pembelajaran daring.

\section{Metode}

Metode penelitian ini mengacu pada pendekatan penelitian kuantitatif. Metode penelitian semi eksperimental plan kuantitatif merupakan penelitian yang memberikan perlakuan dan mengukur akibat perlakuan namun tidak menggunakan random sampel untuk menyimpulkan perubahan yang disebabkan perlakuan tersebut. Penelitian semi eksperimen juga bertujuan untuk menyelidiki hubungan dan mengklarifikasi penyebab terjadinya peristiwa. Teknik pengumpulan data penelitian menggunakan teknik kuesioner dan tes hasil belajar. Alat yang digunakan untuk mengumpulkan data yaitu angket dan tes hasil belajar peserta didik.

Populasi penelitian adalah peserta didik semester 3 dan 5 dengan jumlah 40 orang, untuk Program Keahlian Teknik Elektronika dengan Kompetensi Keahlian Teknik Audio Video di SMK Negeri 1 Karimun. Teknik pengambilan sampel (sampling) yang digunakan yaitu purposive sampling (purposive testing). Purposive sampling (Purposive testing) adalah salah satu jenis teknik pengambilan sampel yang biasa digunakan dalam penelitian ilmiah. Menurut Sugiyono (2008), purposive sampling adalah teknik pengambilan sampel dengan menentukan kriteria-kriteria tertentu. Purposive sampling juga dikenal sebagai judgement, selective atau subyektif sampling. Tujuan utama dari purposive sampling adalah untuk mendapatkan hasil sampel yang secara logis bisa dianggap perwakilan dari populasi. Sampel yang diambil untuk penelitian ini adalah kelas XI dan XII Program Keahlian Teknik Elektronika Kompetensi Keahlian Teknik Audio Video dengan jumlah populasi 40 orang dan besarnya sample yang telah ditentukan adalah 20 orang. Kelas kontrol adalah kelas XI dan kelas eksperimen adalah kelas XII. Untuk menentukan berapa jumlah sample tersebut digunakanlah perbandingan antara jumlah tiap kelas dibagi dengan jumlah total dari kedua kelas (jumlah populasi) dan dikalikan dengan jumlah sample yang telah ditetapkan sebelumnya. Kelas kontrol berjumlah 8 siswa dan kelas eksperimen berjumlah 12 siswa.

Setelah information terkumpul, maka selanjutnya information tersebut akan di analisis menggunakan measurement (statistic) deskriptif, persentase, dan uji T. Measurement (statistic) deskriptif digunakan untuk mengetahui gambaran information terkait variabel penelitian. Persentase digunakan untuk mencari persentase peningkatan hasil belajar sebelum dan sesudah menerapkan media pembelajaran dengan Kvisoft flipbook maker dan uji T digunakan untuk menguji peningkatan hasil belajar sebelum dan sesudah menggunakan media pembelajaran interaktif yaitu Kvisoft flipbook maker. Sebelum dilakukan perhitungan persentase dan uji $\mathrm{T}$, information tersebut terlebih dahulu dilakukan uji persyaratan analisis menggunakan uji normalitas dan uji homogenitas. Pengujian persyaratan analisis dilakukan untuk mengetahui informationt ersebut ordinary dan homogen atau tidak.

\section{Hasil dan Pembahasan Hasil}

Kvisoft Flipbook maker adalah perangkat lunak yang handal yang dirancang untuk mengkonversi file PDF ke halaman balik publikasi digital atau digital book (Neng dan Dandan, 2017:26). Perangkat lunak ini dapat mengubah tampilan file PDF menjadi lebih menarik seperti layaknya sebuah buku. Berdasarkan information yang diperoleh, perhitungan 
deskriptif Kvisoft flipbook maker dapat ditunjukkan pada Tabel 1.

Tabel 1. Hasil Perhitungan Deskriptif Kvisoft flipbook maker

\begin{tabular}{lcc}
\hline \multicolumn{1}{c}{ Statistik } & Kelas kontrol & Kelas eksperimen \\
\hline Mean & 59,38 & 55,00 \\
Median & 57,50 & 52,50 \\
Mode & 45 & $45^{\mathrm{a}}$ \\
Std. Deviation & 14,252 & 8,790 \\
Sum & 475 & 660 \\
\hline
\end{tabular}

Dari tabel diatas diketahui nilai rata-rata deskriptif Kvisoft flipbook maker untuk kelas kontrol sebesar 59,38, median sebesar 57,50, modus sebesar 45, dan nilai standar deviasi sebesar 14,252. Sedangkan untuk kelas eksperimen diketahui nilai rata-rata deskriptif Kvisoft flipbook maker sebesar 55,00, median sebesar 52,50, modus sebesar 45, dan nilai standar deviasi sebesar 8,790. Bentuk diagram histogram dari hasil perhitungan dari tabel diatas dapat dilihat pada Gambar 1.

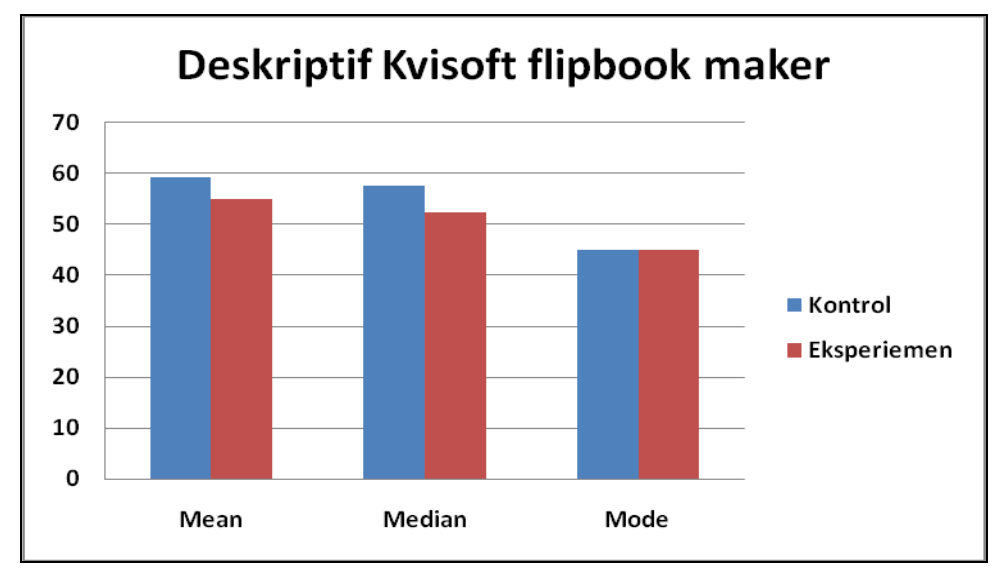

Gambar 1. Histogram Deskriptif Kvisoft Flipbook Maker

Hasil belajar yang diteliti dalam penelitian ini adalah hasil belajar peserta didik sebelum dan sesudah penggunaan media pembelajaran interaktif berupa E-Modul dengan menggunakan aplikasi Kvisoft flipbook maker. Dibawah ini adalah Tabel 3 yang menjelaskan hasil perhitungan deskriptif dari hasil belajar untuk kelas kontrol dan eksperimen. Dimana hasil belajar yang dinilai adalah hasil belajar setelah menerapkan E-Modul sebagai media pembelajaran yang menggunakan aplikasi Kvisoft flipbook maker. Tes yang diberikan berupa soal pilihan ganda. Berikut hasil perhitungan deskriptif hasil belajar setelah dan sebelum penggunaan Kvisoft flipbook maker.

Tabel 2. Hasil Perhitungan Deskriptif Hasil Belajar

\begin{tabular}{lcccc}
\hline \multirow{2}{*}{ Statistics } & \multicolumn{2}{c}{ Kelas Kontrol } & \multicolumn{2}{c}{ Kelas Eksperimen } \\
\cline { 2 - 5 } & Sebelum & Setelah & Sebelum & Setelah \\
\hline Mean & 56,00 & 73,38 & 57,42 & 65,00 \\
Median & 55,00 & 72,50 & 56,00 & 62,50 \\
Mode & 40 & $70^{\mathrm{a}}$ & $48^{\mathrm{a}}$ & 60 \\
Std. Deviation & 15,602 & 8,847 & 8,185 & 10,660 \\
Sum & 448 & 587 & 689 & 780 \\
\hline
\end{tabular}


Dari Tabel 2 diketahui nilai rata-rata deskriptif hasil belajar untuk kelas kontrol sebelum dan sesudah menggunakan Kvisoft flipbook maker adalah sebesar 56 dan 73,58, median sebesar 55 dan 72,50, modus sebesar 40 dan 70, nilai standar deviasi sebesar 15,602 dan 8,847 . Sedangkan untuk kelas eksperimen diketahui nilai rata-rata deskriptif hasil belajar untuk kelas eksperimen sebelum dan sesudah menggunakan Kvisoft flipbook maker adalah sebesar 57,42 dan 65, median sebesar 56 dan 62,50, modus sebesar 48 dan 60, nilai standar deviasi sebesar 8,185 dan 10,66. Bentuk diagram histogram dari hasil perhitungan dari tabel diatas dapat dilihat pada Gambar 2.

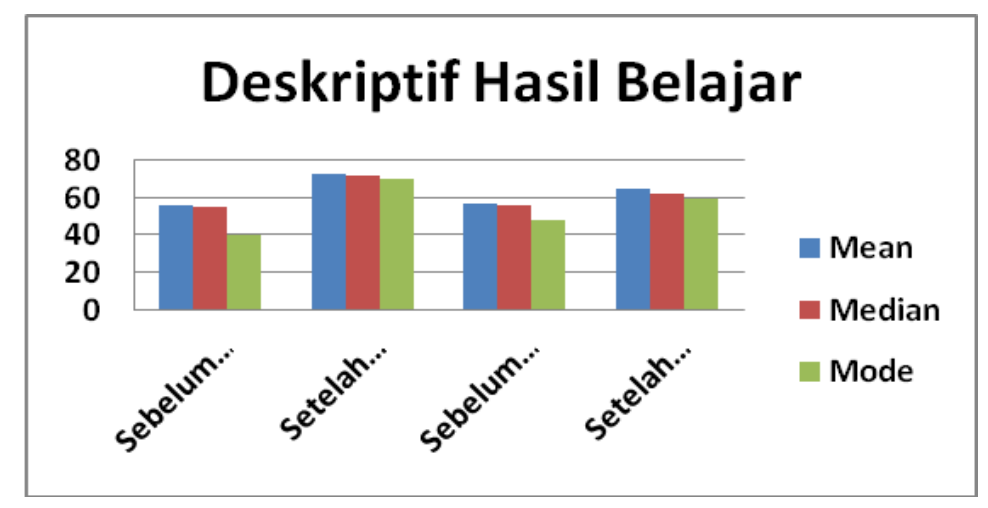

Gambar 2. Histogram Deskriptif Hasil Belajar

Uji hipotesis bisa dilakukan apabila terlebih dahulu dilakukan uji prasyarat analisis untuk menguji data yang diperoleh apakah sudah memenuhi persyaratan untuk dilakukan uji hipotesis. Uji prasyarat analisis yang digunakan yaitu uji normalitas dan uji homogenitas. Dimana sebuah data dapat dikatakan normal apabila nilai sig $>0,05$. Sedangkan Uji homogenitas dikatakan homogen apabila nilai sig $>0,05$.

Tabel 3. Hasil Uji Normalitas Data

\begin{tabular}{lcccccc}
\hline \multicolumn{1}{c}{ Kelompok } & \multicolumn{2}{c}{ Kolmogorov-Smirnov } & \multicolumn{3}{c}{ Shapiro-Wilk } \\
& Statistic & df & Sig. & Statistic & df & Sig. \\
\hline Kelas Kontrol & 0,149 & 8 & $0,200^{*}$ & 0,975 & 8 & 0,935 \\
Kelas Eksperimen & 0,180 & 12 & $0,200^{*}$ & 0,945 & 12 & 0,564 \\
\hline
\end{tabular}

Berdasarkan Tabel 3 hasil uji normalitas data diatas, diketahui bahwa nilai signifikansi kelas kontrol sebesar 0,935 lebih besar dari 0,05 atau 0,935 >0,05, sedangkan nilai signifikansi kelas eksperimen sebesar 0,564 lebih besar dari 0,05 atau 0,564>0,05. Maka sesuai dengan dasar pengambilan keputusan dalam uji normalitas diatas dapat disimpulkan bahwa data berdistribusi normal. Dengan demikian, asumsi atau persyaratan normalitas dalam model regresi sudah terpenuhi. Selanjutnya uji prasyarat analisis yang digunakan dalam penelitian ini adalah uji homogenitas.

Tabel 4. Hasil Uji Homogenitas Data

\begin{tabular}{llcccc}
\hline \multicolumn{1}{c}{ Statistik } & $\begin{array}{c}\text { Levene } \\
\text { Statistic }\end{array}$ & df1 & df2 & Sig. \\
\hline Hasil Belajar Setelah & Based on Mean & 0,226 & 1 & 18 & 0,640 \\
$\begin{array}{l}\text { Menggunakan Kvisoft } \\
\text { Flipbook Maker }\end{array}$ & $\begin{array}{l}\text { Based on Median } \\
\text { Based on Median and } \\
\text { with adjusted df }\end{array}$ & 0,197 & 1 & 18 & 0,662 \\
& $\begin{array}{l}\text { Based on trimmed } \\
\text { mean }\end{array}$ & 0,226 & 1 & 16,295 & 0,663 \\
\hline
\end{tabular}


Berdasarkan Tabel 4. Hasil Uji Homogenitas data diatas, diketahui nilai sig. Rata-rata yang terdapat pada kelas kontrol dan kelas eksperimen adalah sebesar 0,640. Dikarenakan hasil sig. > 0,05 atau 0,640>0,05 maka dapat disimpulkan bahwa varians data dari nilai kelas kontrol dan eksperimen adalah sama atau homogen. Data yang didapat dinyatakan normal dan homogen sehingga bisa digunakan untuk uji hipotesis dalam penelitian. Untuk melihat terjadinya peningkatan hasil belajar peserta didik sebelum dan sesudah digunakan media pembelajaran interaktif berupa Kvisoft flipbook maker, peneliti menggunakan uji hipotesis Paired T-Test.

Tabel 5. Paired T-Test Kelas Kontrol

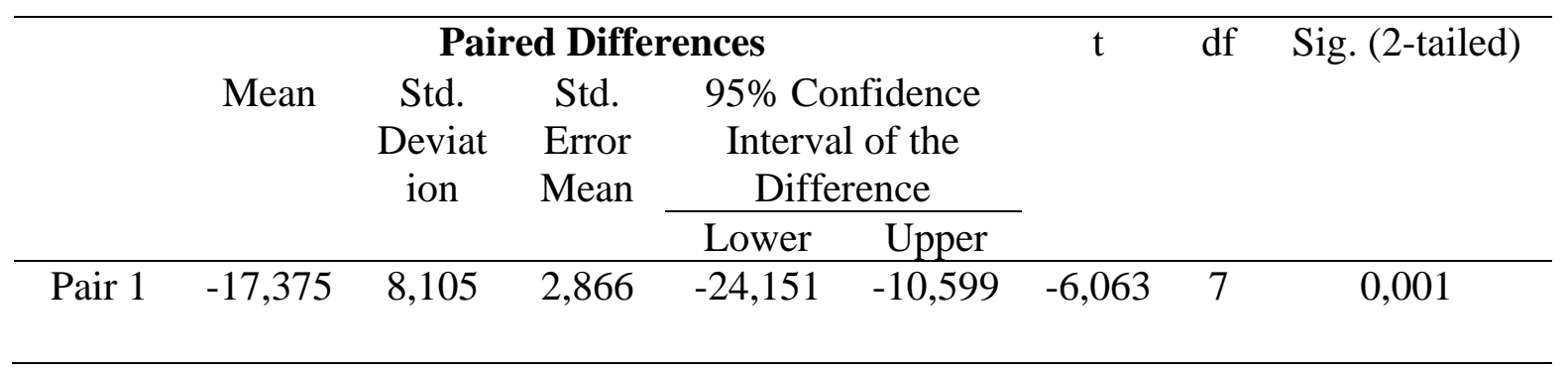

Tabel 5 menunjukkan hasil perhitungan deskriptif sebelum dan sesudah penggunaan Kvisoft flipbook maker, yaitu rata-rata sebelum untuk kelas kontrol sebesar 59,38 dan sesudahnya sebesar 73,38. Dari hasil perhitungan ini dapat sama-sama kita lihat bahwa terdapatnya perbedaan nilai peserta didik sebelum dan sesudah menggunakan Kvisoft flipbook maker untuk materi teknik pembuatan PCB secara manual. Tabel 5 merupakan hasil uji hipotesis Paired T-Test untuk kelas kontrol dengan kepercayaan 95\%, dimana diperoleh nilai signifikasi $0,001<0,05$, maka hipotesis diterima. Dari data diatas dapat kita simpulkan bahwa terdapat peningkatan hasil belajar peserta didik sebelum dan sesudah diterapkan materi teknik pembuatan PCB secara manual dengan media pembelajaran berupa E-Modul yang menggunakan aplikasi Kvisoft flipbook maker.

Tabel 6. Paired T-Test Kelas Eksperimen

\begin{tabular}{|c|c|c|c|c|c|c|c|c|}
\hline & \multicolumn{5}{|c|}{ Paired Differences } & \multirow{3}{*}{\multicolumn{2}{|c|}{$\mathrm{df}$}} & \multirow[t]{3}{*}{ Sig. (2-tailed) } \\
\hline & \multirow[t]{2}{*}{ Mean } & \multirow[t]{2}{*}{$\begin{array}{l}\text { Std. } \\
\text { Deviat } \\
\text { ion }\end{array}$} & \multirow[t]{2}{*}{$\begin{array}{l}\text { Std. } \\
\text { Error } \\
\text { Mean }\end{array}$} & \multicolumn{2}{|c|}{$\begin{array}{l}\text { 95\% Confidence } \\
\text { Interval of the } \\
\text { Difference }\end{array}$} & & & \\
\hline & & & & Lower & Upper & & & \\
\hline Pair 1 & $-7,583$ & 3,777 & 1,090 & $-9,983$ & $-5,184$ & $-6,955$ & 11 & 0,000 \\
\hline
\end{tabular}

Tabel 6 menunjukkan hasil perhitungan deskriptif sebelum dan sesudah penggunaan Kvisoft flipbook maker, yaitu rata-rata sebelum untuk kelas eksperimen sebesar 55,00 dan sesudahnya sebesar 65. Dari hasil perhitungan ini dapat sama-sama kita lihat bahwa terdapatnya perbedaan nilai peserta didik sebelum dan sesudah menggunakan Kvisoft flipbook maker untuk materi teknik pembuatan PCB secara manual. Tabel 6 merupakan hasil uji hipotesis Paired T-Test untuk kelas eksperimen dengan kepercayaan 95\%, dimana diperoleh nilai signifikasi $0,000<0,05$, maka hipotesis diterima. Dari data diatas dapat kita simpulkan bahwa terdapat peningkatan hasil belajar peserta didik sebelum dan sesudah diterapkan materi teknik pembuatan PCB secara manual dengan media pembelajaran berupa E-Modul yang menggunakan aplikasi Kvisoft flipbook maker. 


\section{Pembahasan Hasil Penelitian}

Hasil penelitian menunjukkan bahwa terdapat perbedaan secara simultan hasil belajar siswa antara kelompok siswa yang mengikuti pembelajaran dengan E-modul aplikasi Kvisoft flipbook maker dengan kelompok siswa yang mengikuti pembelajaran dengan menerapkan media berupa gambar. Hal tersebut menunjukkan bahwa penggunaan media pembelajaran interaktif berupa E-Modul yang menggunakan aplikasi Kvisoft flipbook maker dapat meningkatkan hasil belajar siswa.

Pertama terdapat perbedaan hasil belajar siswa yang belajar menggunakan e-modul aplikasi Kvisoft flipbook maker. Kegiatan pembelajaran di kelas eksperimen siswa selama pembelajaran daring lebih mudah memahami materi. Selain itu, media ini memberikan kesempatan bagi siswa untuk lebih mandiri dan bertanggungjawab dalam menyelesaikan tugas yang telah diberikan selama pembelajaran daring. Hal ini berdampak positif pada hasil belajar siswa. Hasil belajar merupakan kemampuan yang dimiliki peserta didik setelah menerima pembelajaran (Sarnoko et al., 2016; Sulianto et al., 2019). Kemampuan tersebut merupakan aspek kognitif, efektif dan psikomotorik. Hasil belajar peserta didik dapat dilihat melalui kegiatan evaluasi yang bertujuan untuk mendapatkan data penilaian yang menunjukkan tingkat kemampuan peserta didik dalam pembelajaran (Latifah et al., 2020). EModul merupakan media pembelajaran yang menggunakan aplikasi Kvisoft flipbook maker. Aplikasi ini mampu mengubah media pembelajaran yang dulunya berupa konvensional sekarang menjadi media pembelajaran intraktif, yang mana biasa tenaga pendidik menggunakan media pembelajaran konvensional berupa powerpoint tapi sekarang menjadi $E$ Modul yang menakjubkan dengan berbagai format. Penggunaan media pembelajaran ini diharapkan dapat memberikan dampak positif dalam pembelajaran.

Kedua, penggunaan media pembelajaran berupa E-Modul yang menggunakan aplikasi Kvisoft flipbook maker memberikan pengaruh positif terhadap hasil pembelajaran sehingga bisa direkomendasikan untuk pembelajaran selanjutnya. E-modul aplikasi Kvisoft flipbook maker memberikan kesempatan kepada siswa untuk belajar lebih mandiri dan bermakna dalam proses pembelajaran daring. Modul adalah media atau sarana pembelajaran yang berisi materi, metode, batasan-batasan materi pembelajaran, petunjuk kegiatan pembelajaran, latihan dan cara mengevaluasi yang dirancang secara sistematis dan menarik untuk mencapai kompetensi yang diharapkan dan digunakan secara mandiri (Haryanto, Asrial et al., 2019; Wibowo, 2018). Aplikasi kvisoft flipbook maker adalah salah satu aplikasi yang mendukung sebagai media pembelajaran yang akan membantu dalam proses pembelajaran karena aplikasi ini tidak terpaku hanya pada tulisan-tulisan saja tetapi bisa dimasukan sebuah animasi gerak, video, dan audio yang bisa menjadikan sebuah interaktif media pembelajaran yang menarik sehingga pembelajaran menjadi tidak monoton (Fonda \& Sumargiyani, 2018).

Berdasarkan hasil temuan dan pembahasan yang telah dipaparkan, penelitian ini memberikan kontribusi pada penelitian hasil belajar siswa dapat meningkat menggunakan EModul yang menggunakan aplikasi Kvisoft flipbook maker. Selanjutnya, rekomendasi yang dapat diberikan berdasarkan hasil penelitian ini mendorong peneliti lain untuk mengkaji lebih lanjut penerapan media E-Modul yang menggunakan aplikasi Kvisoft flipbook maker. Kvisoft flipbook maker adalah aplikasi untuk membuat e-book, E-Modul, e-paper, dan e-magazine yang hasil penyajiannya dalam bentuk elektronik didalamnya mampu menampilkan simulasisimulasi yang interaktif dengan memadukan teks, gambar, sound, video, animasi, dan navigasi sehingga pembelajaran dapat berlangsung lebih menarik dan menyenangkan serta membuat peserta didik lebih tertarik dalam mengikuti pembelajaran dengan materi teknik pembuatan PCB secara manual. 


\section{Simpulan}

Pembelajran daring materi pembelajaran dituang dalam bentuk E-Modul, penggunaan media pembelajaran interaktif berupa E-Modul ini yang menggunakan aplikasi Kvisoft flipbook maker peserta didik untuk kelompok kelas kontrol dan eksperimen terjadi peningkatan dari hasil belajar yang di dapat oleh peserta didik yang diikuti dengan, kehadiran peserta didik dalam pembelajaran walau dalam bentuk maya, dan peningkatan nilai yang didapat oleh peserta didik pada materi teknik pembuatan PCB secara manual setelah menggunakan E-Modul yang menggunakan aplikasi Kvisoft flipbook maker. Implikasi penelitian ini dapat membantu peserta didik semangat dan termotivasi dalam menjalani pembelajaran.

\section{Daftar Rujukan}

Aka, K. A. (2017). Pemanfaatan Teknologi Informasi dan Komunikasi (TIK) sebagai Wujud Inovasi Sumber Belajar di Sekolah Dasar. Jurnal Pendidikan Dan Pembelajaran Sekolah Dasar, 1(2), 28-37. http://journal.umsurabaya.ac.id/index.php/pgsd/article/view/1041/724.

Anugrahana, A. (2020). Hambatan, Solusi dan Harapan : Pembelajaran Daring Selama Masa Pandemi Covid-19 Oleh Guru Sekolah Dasar. Scholaria: Jurnal Pendidikan Dan Kebudayaan, 10(3), 282-289. https://ejournal.uksw.edu/scholaria/article/view/4033.

Asmuni, A. (2020). Problematika Pembelajaran Daring di Masa Pandemi Covid-19 dan Solusi Pemecahannya. Jurnal Paedagogy, 7(4), 281. https://doi.org/10.33394/jp.v7i4.2941.

Dewi, R. K., Wardani, S., Wijayati, N., \& Sumarni, W. (2019). Demand of ICT-based chemistry learning media in the disruptive era. International Journal of Evaluation and Research in Education, 8(2), 265-270. https://doi.org/10.11591/ijere.v8i2.17107.

Ferdianto, F., \& Nurulfatwa, D. (2019). 3D Page Flip Professional: Enhance of Representation Mathematical Ability on Linear Equation in One Variable. Journal of Physics: Conference Series, 1188(1), 012043.

Fonda, A., \& Sumargiyani. (2018). The Developing Math Electronic Module With Scientific Approach Using Kvisoft Flipbook Maker Pro For Xi Grade Of Senior High School Students. Journal of Mathematics Education, 7(2), 109-122. https://doi.org/10.22460/infinity.v7i2.p109-122.

Haryanto, Asrial, M., Ernawati, D. W., Syahri, W., \& Sanova, A. (2019). E-Worksheet Using Kvisoft Flipbook: Science Process Skills And Student Attitudes. International Journal Of Scientific \& Technology Research, 8(12), 1073-1079.

Hudayati, N., Andayani, Y., \& Junaidi, E. (2021). Pengaruh Persepsi Guru Tentang TIK Terhadap Pemanfaatan Teknologi Informasi dan Komunikasi dalam Pembelajaran IPA SMA/MA Se-Kecamatan Gerung. Chemistry Education Practice, 4(1), 84. https://doi.org/10.29303/cep.v4i1.2233.

Indahini, R. S., Sulton, \& Husna, A. (2018). Pengembangan Multimedia Mobile Learning Pada Mata Pelajaran Simulasi Dan Komunikasi Digita Kelas X SMK. Jurnal Kajian Teknologi Pendidikan, 1(2), 141-148. http://journal2.um.ac.id/index.php/jktp/article/view/3730.

Kristin, F. (2016). Analisis model pembelajaran discovery learning dalam meningkatkan hasil belajar siswa SD. Jurnal Pendidikan Dasar PerKhasa.

Kulagina, K., Leksashova, A., Bolsunovskayaa, M., \& Shirokovaa, S. (2021). Development of a Human Flow Generation Module for Testing Machine Learning Algorithms. 
$\begin{array}{llll}\text { Transportation } \quad \text { Research } & \text { Procedia, } & \text { 783-792. }\end{array}$ https://doi.org/10.1016/j.trpro.2021.02.134.

Kuncahyono. (2018). Pengembangan E-Modul (Modul Digital) dalam Pembelajaran Tematik di Sekolah Dasar. Journal of Madrasah Ibtidaiyah Education, 2(2), 121. https://doi.org/http://dx.doi.org/ 10.32934/jmie.v2i2.75 Copyright.

Kuncahyono, \& Aini, D. F. N. (2020). Pengembangan Pedoman E-Modul Berorientasi Student Active Learning Sebagai Pendukung Pembelajaran di Sekolah Dasar. Jurnal Pendidikan Dasar Nusantara, 5(2), 292-304. https://doi.org/10.29407/jpdn.v5i2.13999.

Latifah, N., Ashari, A., \& Kurniawan, E. S. (2020). Pengembangan e-Modul Fisika Untuk Meningkatkan Kemampuan Berpikir Kritis Peserta Didik. Jurnal Inovasi Pendidikan Sains (JIPS), 1(1), 1-7. https://doi.org/doi.org/10.37729/jips.v1i1.570.

Nakayama, M, \& Yamamoto. (2006). Investigating the impact of learner characteristics on blended learning among Japanese Students. Proceedings of the International Conference on E-Learning, ICEL, 2006-Janua(3), 361-370.

Novianto, L. A., Degeng, I. N. S., \& Wedi, A. (2018). Pengembangan Multimedia Interaktif Mata Pelajaran IPA Pokok Bahasan Sistem Peredaran Darah Manusia Untuk Kelas VIII SMP Wahid Hasyim Malang. Jurnal Kurikulum Teknologi Pendidikan (JKTP) Universitas Negeri Malang, 1(3), 257-263.

Ota, M. K., Djou, A. M. G., \& Numbah, F. F. (2021). Problematika Pembelajaran Daring Siswa Kelas Vii Smpn. Jurnal Pengabdian Masyarakat, 2(1), 74-81. https://doi.org/10.37478/mahajana.v2i1.769.

Pakpahan, R., \& Fitriani, Y. (2020). Analisa Pemafaatan Teknologi Informasi Dalam Pemeblajaran Jarak Jauh Di Tengah Pandemi Virus Corona Covid-19. JISAMAR (Journal of Information System, Applied, Management, Accounting and Researh), 4(2), 30-36. http://journal.stmikjayakarta.ac.id/index.php/jisamar/article/view/181.

Prasojo, L. D., Habibi, A., Yaakob, M. F. M., Mukminin, A., Haswindy, S., \& Sofwan, M. (2019). An explanatory sequential study on indonesian principals' perceptions on ICT integration barriers. Electronic Journal of E-Learning, 17(1), 1-10.

Puspitawangi, R.K., et. al. (2017). Pengaruh Model Pembelajaran Kooperatif Tipe Talking Stick Berbantuan Media Audio Visual Terhadap Hasil Belajar Ips. MIMBAR PGSD Undiksha, 5(2).

Rahmadi, I. F., Khaerudin, K., \& Kustandi, C. (2018). Kebutuhan Sumber Belajar Mahasiswa yang Mendukung Pembelajaran Berbasis Teknologi Informasi dan Komunikasi di Perguruan Tinggi. JTP - Jurnal Teknologi Pendidikan, 20(2), 120-136. https://doi.org/10.21009/jtp.v20i2.8620.

Rigianti, H. A. (2020). Kendala Pembelajaran Daring Guru Sekolah Dasar Di Kabupaten Banjarnegara. Jurnal Elementary School, 7(2), 297-302. https://doi.org/10.31316/esjurnal.v7i2.768.

Rivalina, R. (2014). Kompetensi Teknologi Informasi Dan Komunikasi Guru Dalam Peningkatan Kualitas Pembelajaran. Jurnal Teknodik, 18(2), 165-176.

Sa'diyah, K. (2021). Pengembagan E-Modul Berbasis Digital Flipbook Untuk Mempermudah Pembelajaran. EDUKATIF: JURNAL ILMU PENDIDIKAN, 3(4), 1298-1308. https://doi.org/10.31004/edukatif.v3i4.561.

Sarnoko, Ruminiati, \& Setyosari, P. (2016). Penerapan Pendekatan Savi berbantuan Video Pembelajaran untuk Meningkatkan Aktivitas dan Hasil Belajar IPS Siswa Kelas IV SDN 1 Sanan Girimarto Wonogiri. Jurnal Pendidikan, 7(1). https://doi.org/http://dx.doi.org/10.17977/jp.v1i7.6524. 
Sasmito, D. R. P., \& Trimulyono, G. (2019). Development of Funginopoly (Fungi Monopoly) Game Media In Fungi Material For 10th Grade Senior High School to Increase Student's Level of Concept Understanding. BioEdu, 8(3), 51-60.

Siahaan, M. (2020). Dampak Pandemi Covid-19 Terhadap Dunia Pendidikan. Jurnal Kajian Ilmiah (JKI), 20(1), 1-3.

Sulianto, J., Purnamasari, V., \& Febriarianto, B. (2019). Pengaruh Model Pembelajaran Think-Pair-Share terhadap Hasil Belajar Siswa Kelas V (Lima) Materi Organ Tubuh Manusia dan Hewan. Internasional Journal of Elementary Education, 3(2), 124-131. https://doi.org/10.23887/ijee.v3i2.18515.

Susilowati, S., Sajidan, S., \& Ramli, M. (2018). Keefektifan perangkat pembelajaran berbasis inquiry lesson untuk meningkatkan keterampilan berpikir kritis siswa. Jurnal Penelitian Dan Evaluasi Pendidikan, 22(1), 49-60. https://doi.org/10.21831/pep.v22i1.17836.

Suwasono. (2013). Pengembangan E-Modul Online Elektronika Analog Pada Pendidikan Jarak Jauh. Teknologi Dan Kejuruan, 36(1), 51-62.

Szép, S. G. (2017). Konzeption und Implementierung eines neuartigen E-Learning-Moduls mit EbM-Lerninhalten im Fach ZahnerhaltungskundeConception and implementation of a novel E-learning module with EbM learning contents in operative dentistry. Zeitschrift Für Evidenz, Fortbildung Und Qualität Im Gesundheitswesen, 127-128, 72-78. https://doi.org/10.1016/j.zefq.2017.09.001.

Wibowo, E. (2018). Pengembangan Bahan Ajar E-Modul Dengan Menggunakan Aplikasi Kvisoft Flipbook Maker. Universitas Islam Negeri (Uin).

Wibowo, E., \& Pratiwi, D. D. (2018). Pengembangan Bahan Ajar Menggunakan Aplikasi Kvisoft Flipbook Maker Materi Himpunan. Desimal: Jurnal Matematika, 1(2), 147. https://doi.org/10.24042/djm.v1i2.2279.

Widiyono, A. (2020). Efektifitas Perkuliahan Daring (Online) pada Mahasiswa PGSD di Saat Pandemi Covid 19. Jurnal Pendidikan, 8(2), 169-177. https://doi.org/10.36232/pendidikan.v8i2.458.

Wijayanti, R. M., \& Fauziah, P. Y. (2020). Perspektif dan Peran Orangtua dalam Program PJJ Masa Pandemi Covid-19 di Paud. Jurnal Obsesi : Jurnal Pendidikan Anak Usia Dini, 5(2), 1304-1312. https://doi.org/10.31004/obsesi.v5i2.768.

Winatha, K. R., Suharsono, N., \& Agustin, K. (2018). Pengembangan E-Modul Interaktif Berbasis Proyek Matematika. Jurnal Pendidikan Teknologi Dan Kejuruan, 4(2), 188199. https://ejournal.undiksha.ac.id/index.php/JPTK/article/viewFile/14021/9438. 